\title{
TRANSFORMATION OF TRADITIONAL SETTLEMENTS AND DISASTER VULNERABILITY
}

\author{
I Nyoman Gede Maha Putra ${ }^{1}$ \\ ${ }^{1}$ Department of Architecture, Faculty of Engineering and Planning, Universitas Warmadewa \\ Corresponding Author: gedemahaputra@gmail.com \\ 2020 \\ Accepted: 26 Januari \\ 2020 \\ Available online: 30 April \\ 2020
}

\begin{abstract}
As a setting of life and cultural products made by humans, settlements always undergo transformation along with the dynamics of their inhabitants' lives. The dynamics of occupants, in addition to being impacted by the development of local knowledge, changes in the way humans respond to climate, and cultural transformation, are also influenced by external factors. External factors that influence settlement transformation can arise in the form of urbanisation, changes in social and political systems, economics, and technological development. In traditional societies, natural threats are predictable and conquerable. The transformation of settlements can take place in the same frame, promoting natural considerations, or in a different frame with the existence of new ideas and knowledge and technology coming from the outside. To be able to understand the transformation of traditional settlements and their transformations in relation to disaster vulnerability, this paper evaluated the causing factors, patterns, and consequences resulted from the transformation of settlements. For this reason, urban morphological studies are applied as an evaluation method. The results of the evaluation of settlement transformations reveal that traditional settlements are farther away leaving natural-harmony patterns at the root of their existence. Economic approach has replaced the cosmological-based settlement. It is recommended that natural site characteristic should be taken into consideration in order to avoid natural disaster in the future. This means that the traditional approach is still relevant in contemporary situation.
\end{abstract}

Keywords: Traditional settlements; transformation; disaster vulnerablity

\section{INTRODUCTION}

One of the factors that have always made the majority of today urban residents wary is the rainy season. Our cities are increasingly being hit by disasters as a result of by the abundance of surface water in the rainy season. One of the factors causing the disaster is our behavior as human beings who inhabit the nature. In contrast to other forms of natural disasters, such as volcanoes, earthquakes, tsunamis, or hurricanes, floods and landslides are predictable and, thus, are avoidable if accompanied by adequate knowledge. The present paper explores the development of cities and settlements that originate from traditional villages to their present condition from the perspective of their vulnerability to disasters. The exploration starts from traditional principles turning into the physical environment and its development. In reviewing the developments, the impacting factors and the effects on the resilience of an area are assessed. The argument to be proven is that the development of a traditional village is influenced by many factors, especially politics and economics. This development has made the disaster vulnerability of a settlement rooted in tradition increased. To prove this argument, a traditional settlement located in Denpasar City is used as a case sample.

The founders of traditional villages, were very skilled in the efforts to avoid natural disasters. In the past, human life almost united with nature, without insulation. Knowledge about the character and nature of the earth is the basis in building settlements and various facilities. An understanding of astronomy, the movement of the moon and the sun, as well as an understanding of the surface of the earth: mountains, hills, rivers, lakes and seas are translated into a scheme called cosmology 
(Oliver, 2007). Communities in various regions in Indonesia use this knowledge to organise their lives.

The cosmological guide, which is the translation of the universe, is constructed as a guide to living in harmony with nature by traditional societies. As a guideline, the concept of cosmology is applied in various fields, ranging from rituals to the formed environments or settlements. In the context of Indonesia, the Balinese, for example, believe that nature shall be respected and revered just like human's respect or value their mothers. Various rituals are carried out before opening a farm, starting from planting rice, maintaining plants until harvesting activities (Waterson, 1997). Astrology knowledge and appropriate day calculations are applied in order that everything is compatible and in harmony with nature (Oliver, 2007).

The structuring of the settlement environment also applies knowledge about the appropriate days based on knowledge of seasons and astrology. Furthermore, the location of determining settlements chosen from certain sites is also carried out with cosmological considerations. Traditional settlements of inhabitants living in the mountains are on ridge hills. These sites are safe from the threat of flooding, making it easier for residents to monitor whenever there are wild animals coming, but the location chosen represents the one that is free from landslides. The place or building with the most important function is placed in the safest location: it can be in the upstream area or in the middle of a settlement. Residents' houses are established at locations far from river banks, ravines or the seashore for safety. These safe distances are then translated into perimeter.

The traditional methods of building and organising the environment is passed on from one generation to the next through a vernacular process (Waterson, 1997). In this process of transmission, the evaluation, improvement, revision and development of new knowledge produced by each generation are possible. This process makes the traditional settlements compatible with the dynamic lives of its inhabitants, in addition to their nature. Throughout these processes, creationcontinuation-evaluation and revision, make the relationship between humans and their settlements have strong emotional value to one another (Watson \& Bentley, 2007). In terms of architecture, virtually all traditional architecture in various regions of Indonesia constitutes an earthquake-resistant building with a timber and bamboo connection construction system (see Waterson, 1997). It is speculated that the diversity of system connections in traditional architecture is related to the intensity of the earthquake undergone by the area where the building was established(Permana, 2014). For instance, in regions with higher earthquake frequency, the connection system tends to be more complex and perfect compared to that of regions with lower frequency of earthquake.

Unexplored sites, such as hidden springs, dark natural caves, mountains emitting smoke or high surging oceans are preserved and guarded. Its strength has not been understood, so its potential danger is difficult to predict (Bourdier \& Alsayyad, 1989). Knowledge gained by 'reading' and understanding the nature is managed and disseminated within an organisational structure of traditional society. This traditional society has a close kinship. Even the government system is often based on this kinship system (Bourdier \& Al-Sadyad, 1989). The settlement is built on several pricniples including economic reason (Sinamides, 2017)

Drastic changes occur when knowledge comes from outside the settlement and is adopted by the community. The process of adopting new ideas can take place in a peaceful or coercive way. During the colonial period, new ideas were introduced by the new government to the traditional government. To fulfill its economic ambitions, the colonial government structured its colonial cities with the principle of economic improvement. A new layout was introduced. Traditional urban centres were connected by ports to facilitate the transportation of agricultural produce and bring western industrial produce to the cities of the colony (King, 1991). These ideas, in some places, had come into conflict since the traditional societies still maintained their traditional patterns. This led the colonial cities to have a dual character: traditional and modern. Changes could also occur in a topdown process of the post-colonial government. A central government agent in the effort to carry out large scale development may relocate a group of people occupying one particular area to other area. This type of development often created tension between the patron and client (Zhang, Wu, \& Zhong, 2018). The top-down process is also viewed as a less sustainable approach. Therefore, it is often criticized by scholars and people in general. A bottom-up development approach is then proposed in order to create a more applicable and sustainable environment (Dias, Keriminiyage, Amaratunga, \& Curwell, 2018). A place that is developed in a bottom-up approach may increase the sense of belonging of the inhabitant. This in turn, will increase the value of the place where the resident may have a better health, social, and economic quality (Carmona, 2019). However, the bottom-up approach may also weaken the role of central government in maintaining its power. Effort had been 
made by the Government of the Republic of Indonesia in to maintain the balance of top-down and bottom up approach in planning (Hudalah \& Woltjer, 2007).

In Indonesia, different regions had been occupied by different colonisers, thus affecting the diversity of the city's image. Cities in the eastern part of Indonesia underwent colonialism from Spanish and Portuguese for quite a long time. The architecture of these countries is mostly found in the islands which produce spices, the main commodity sought by the invaders. The western part of Indonesia is influenced by many more nations. Some areas were influenced by Arabic, Indona, and Chinese culture before the Dutch Colonial Government ruled it. This mixture then created a unique regional diversity, combined with traditional settlements (Tjahjono \& Miksic, 2003).

In the view of a number of factors leading the settlement transformation, there are several questions to be addressed in the present paper. These are: If traditional settlements were built with a thick natural environment approach, how would new ideas coming from other regions impact them? Does the development of traditional settlements still maintain propinquity with nature? How does the disaster-prone condition of the traditional settlement look like after being impacted by the ideas coming from outside?

\section{METHOD}

This study is conducted on the premise that settlements are formed and perennially receive improvements and revisions from their inhabitants. In the process of settlement growth, new ideas are introduced to add or can also be to replace the initial ideas since the initial formation of the settlement. For this reason, urban morphology is used to carry out physical evaluations of changes in the form of settlements (Kropf, 2009). In urban morphological study, changes in settlements can be learned from the dynamics of changes in the spatial and physical patterns of the settlements themselves and changes in patterns of activity in the utilisation of spaces therein, both in terms of economic, social, and traditional custom (Boeing, 2018).

In the conduction of this urban morphological study, maps of the settlement of each different year were prepared. The limited availability of maps from government agencies was overcome by drawing up new maps by the author. Maps were made by analysing the government policies, interviewing the local residents and customary stakeholders, and then interpreting the results into spatial information. Spatial information was then arranged on a time frame so year order-based maps are obtained.

In addition to using spatial maps as instruments, data were also collected through interviews with the local residents. On the results of the interview a perceptual analysis was conducted. Spatial analysis and perceptual analysis are two analytical tools used in this study given that a settlement does not only cover issues related to physical elements but also about how the physical elements are perceived by space users (Muhammad, Saruwono, Said, \& Hariri, 2013).

The study was conducted for 3 months at the determined location. Within the span of three months, the research activities carried out were: interviews with village officials to find out the patterns of settlement management; observation to discern the patterns of spatial utilisation and potential problems that may arise related to disaster and to determine the types of disasters that had arisen; and interviews with villagers to find out their perceptions of changes in settlement patterns and physical surveys through measurements to find out physical changes in settlements.

\section{RESULTS AND DISCUSSION}

\subsection{TRANSFORMATION OF TRADITIONAL VILLAGE SETTLEMENT OF PENINJOAN}

In this section, the results of the analysis of data obtained from the field study are presented. The analysis shows that the situation in Peninjoan Village has always changed. These changes are caused by various factors, such as the transfer of the working function of the population, changes in the community's perspective toward the settlements, and, the most important of all is the flow of urbanisation as a result of the development of the centre of Denpasar which makes it economically attractive so it becomes a magnet. The settlements in the Peninjoan area serve convenient locations for building houses for new residents coming to look for jobs in Bali, especially in the Denpasar area. As a result, changes in the patterns of settlements occur, in which, at the initial the area constituted an agricultural area. 


\subsection{Disaster Considerations in the Early Patterns of Peninjoan Village}

Peninjoan Village is located in the northern suburbs of Denpasar City. At present, the settlement is filled with mixed activities, including those related to customs and culture, economic, and social. Historically, the village was a chosen by one of the King of Bali to be a location to perform yoga and achieve moksha. However, regarding which king is still questionable. Reputedly, the king was accompanied by a group of his warriors to travel and at one point they felt the need to take a break. From the place of rest, the king then made observations of the surrounding areas. From the observation process, the word 'peninjauan' derived, which was then changed to 'peninjoan'. The word was then used to name the place from which the king made the observations.

From the observation, it is revealed that there was a beautiful green river, named Tukad Ayu, which is now known as Tukad Ayung. On the banks of this river, in the place considered the most beautiful place, the king did yoga. His followers then built settlements around the place. For its beauty, the place was named Kahyangan, which now serves as the name of a banjar.

Despite the King obtaining Moksha, his followers remained in the place and developed agriculture. The fertility of the land and water flowing throughout the year provides prosperity for the population. Gradually, the settlement attracted the interest of the surrounding inhabitants to open new agricultural lands. The agricultural lands were made in the north and east of the settlements of the followers of the king. New settlements were then built by land owners near their fields. This settlement was later given the name Umah Anyar which in Indonesian is called a new home. This settlement also formed a new banjar named Uma Anyar. To the north of the Banjar Kahyangan and Uma Anyar settlements stretches an unfertile land filled with reeds. New residents arrived and inhabited the area and then referred to as Banjar Ambengan. The three banjars: Kahyangan, Uma Anyar, and Ambengan, are the forerunners of the traditional settlement of Customary Village of Peninjoan.

The Peninjoan Village, which consists of three banjars, is democratically managed by its inhabitants. A Bendesa Adat or the customary leader is elected by all members of each banjar. In the process, each banjar is entitled to submit one candidate to be elected at the village level. The candidate who obtain the most votes is appointed as the leader while the other two candidates are entitled to the secretary and treasurer positions. Thus each banjar is represented in the leadership structure at the village level. Traditionally, this customary unity stands independently despite being affiliated in the Kingdom of Badung. The kingdom has limited authority in decision making because it is fully authorised to villagers led by the leader.

Physically, Peninjoan Village is outflanked by Tukad Ayung in the west and fertile rice fields in the east. Tukad Ayung is located at a considerable distance to the west so the settlement seems to be located on the edge of a cliff. However, the distance between the housing and the edge of a cliff is quite safe. It seems that the placement of these settlements, in addition to considering security factors, also takes into account the economic carrying capacity so it is positioned on less fertile land but still quite close to fertile rice fields (see figure 1).

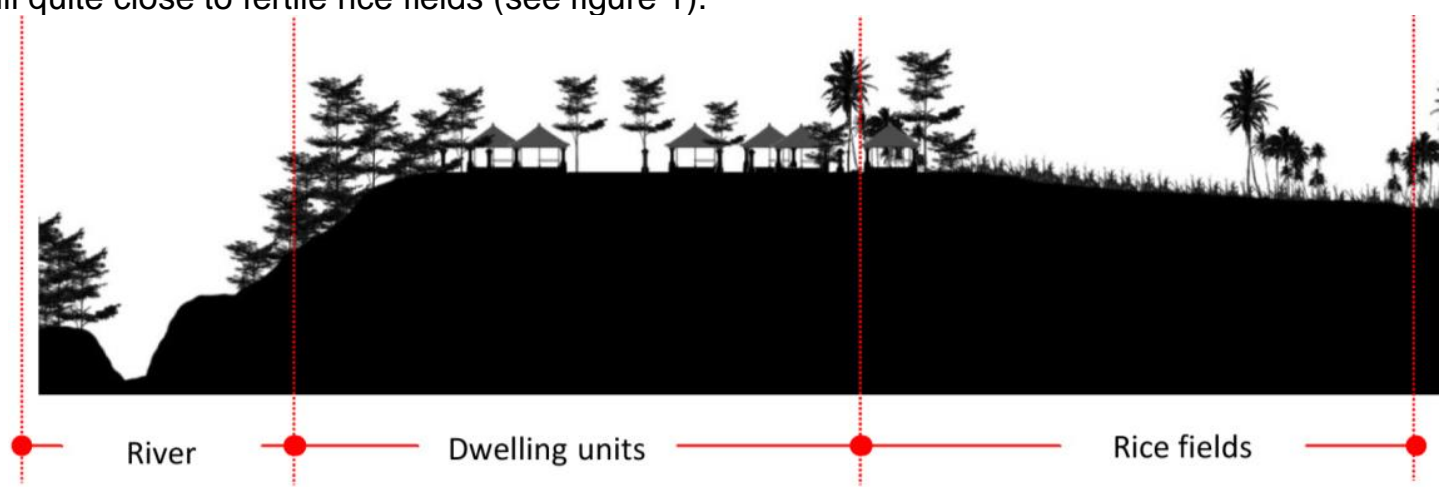

Figure 1. Cross section of Peninjoan Traditional Village Settlement

Source: Building survey, 2016

Spatially, the settlement organised in three banjars is linear-patterned. The area at the southern end of the village belongs to the temple area where, as believed, Raja Bali used to practice Yoga. The area around the temple complex represents a residential area of Banjar Kahyangan community. As an area located close to the city centre, the area is also equipped with a market that supplies the necessities of people as well as serving as a place where residents sell their produce. In the eastern part of Banjar Kahyangan, in a location close to paddy fields, the settlement of Banjar 
Uma Anyar residents is structured. This group is a descendant of farmers who come to oversee their vast rice fields thereat. The area at the end of the village belongs to Banjar Ambengan. The inhabitants living in the area, which was once a reed garden, built their house in a linear pattern (see figure 2).

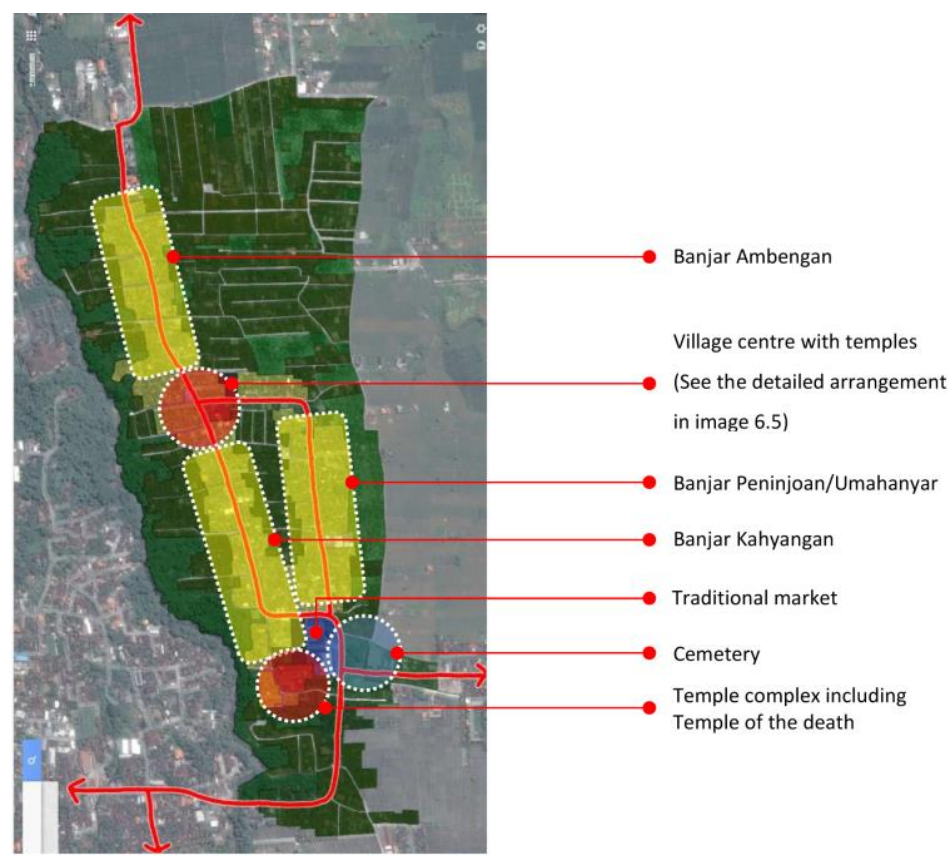

Figure 2. Layout of Peninjoan Traditional Village Settlements Source: Building survey, 2016

The village centre is located around the Pura Desa and Pura Puseh, precisely at the meeting point of the three banjars. The position of the village centre allows the three settlements to be socially connected because in this centre there is an open space in the form of a yard in front of the temple, a banjar hall and another open space in the corner.

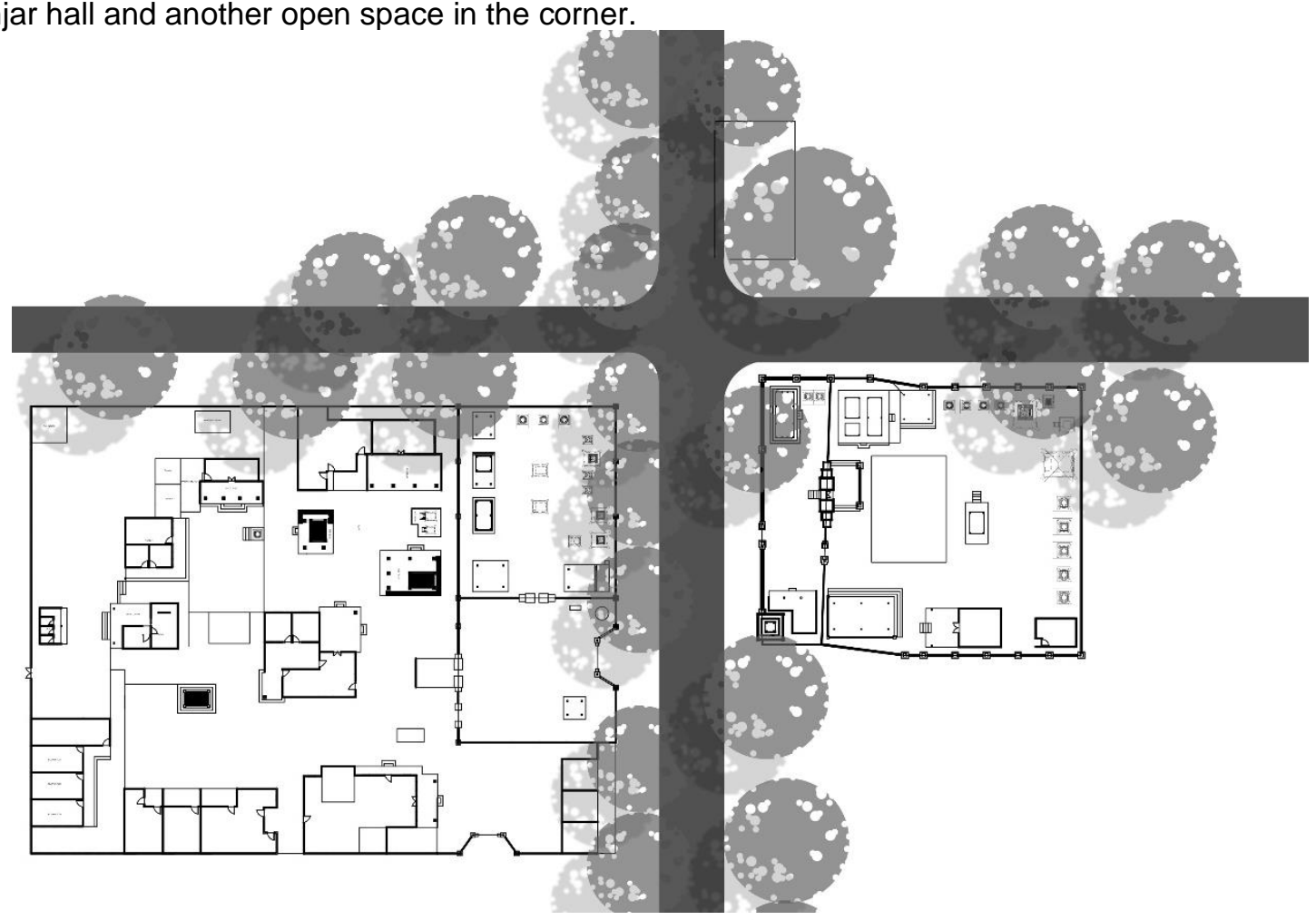

Figure 3. Peninjoan Traditional Village Settlement Village Center

Source: Building survey, 2016

Architecturally, the buildings in Peninjoan village, just like traditional buildings in Bali in general, adopt a wooden frame structure that supports the pyramid roof. These structures are placed 
on an elevated platform. Floor plan is simple-formed with a relatively small building mass so there is no need for complex construction systems. The application of this construction system makes the building resistant to earthquake shakes at certain scales.

The early settlement patterns of the village of Peninjoan indicates that natural factors were given important consideration in establishing a place for settlement. In the guaranty of its economic needs, especially the rice as a staple food, fertile lands were designated as agricultural areas. Human settlements were located on relatively infertile land, near the Ayung River and on the former reed fields. In order to avoid the threat of landslides, the settlements were positioned at a safe distance from the edge of a cliff. In addition to spatial distribution, disaster mitigation in traditional buildings is formed from the selection of simple mass patterns and wooden frame construction systems applied to the architecture of buildings. Open space in the middle of settlements can also be used in emergencies as a safe point for gathering.

\subsection{Flow of Urbanisation and Disaster Vulnerability}

Changes to the patterns and forms of traditional settlements are resulted from the social and economic dynamics that take place in society. In regard to the case of Peninjoan Village, the changes began when Bali joined the Republic of Indonesia in 1950 and Denpasar was appointed as the Provincial Capital in the 1960s. Although it is not located in the centre of the city, the Peninjoan Village receives indirect impacts from this socio-economic-political changes.

After being designated as the Capital City of the Province of Bali, physical development have been mostly done in Denpasar. The city which originally served as the centre of a traditional kingdom has now become the centre of modern administration, economy, education, art and culture. In serving this new function, urban infrastructures are established, both in the form of roads, bridges and buildings.

Economically, a market in the city centre has been established as a centre for distribution of goods at the provincial level. Sanur was developed into a tourism area which subsequently developed very rapidly to this day. Construction of buildings also took place very rapidly.

In terms of infrastructure in the form of road, two ring roads named By-pass Ngurah Rai and Gatot Subroto have been built. The aim was to avoid the flow of transportation between regencies so that they no longer have to enter the city centre, but rather just crossing the edges. However, these roads also connect suburban areas with the city centre. All of these new activities finally made Denpasar very attractive to citizens in the surrounding area, and even from outside the island of Bali. The flow of urbanisation began to peak so the downtown area becomes increasingly congested and land prices are getting higher and higher.

The higher price of lands in the downtown area led the suburban areas to become targets for urbanites to build their settlements. Peninjoan, which is located in the edge of the city, receives an impact because in that area sufficient land at a more affordable price is still available, compared to those in the city centre. Traditional Village, which was originally only located outside the city, is now, with the road, well connected with other areas.

Spatial development, changing the traditional spatial structure of Penonjoan Village, took place when a plot of land, located at the eastern part of Banjar Ambengan, began to be cleared. This land was cleared to meet the need for housing locations for lecturers subserving at several private universities in Denpasar which, in the 1980s, were still concentrated in Denpasar City. In an effort to still consider safety and so as not to interfere with agricultural economic activities, this land remains as a less fertile estate since it is located slightly higher than the paddy field area (see figure 4 left).

A similar pattern, which is to open up new settlements on infertile land, subsequently became a widely adopted pattern. Since the late 1990s, the economy of Denpasar City has increasingly attracted the interest of many people to come and open businesses. The increasing flow of urbanisation requires not less residential land. Areas, which are deemed as not producing economic profit, are targeted to be developed into residential land. Figure 5 in the right shows the pattern of housing development in Traditional Village of Peninjoan at a later stage.

Despite having a similar economic approach, utilisation of infertile land, this second pattern takes risks at the expense of the safety aspect. The land utilised has a relatively close distance to the edge of the cliff of Tukad Ayung. This increases the risk of landslides. Such a development implies that traditional cosmology, which places humans as an inseparable part of the environment, is no longer applied as a consideration in erecting buildings. 

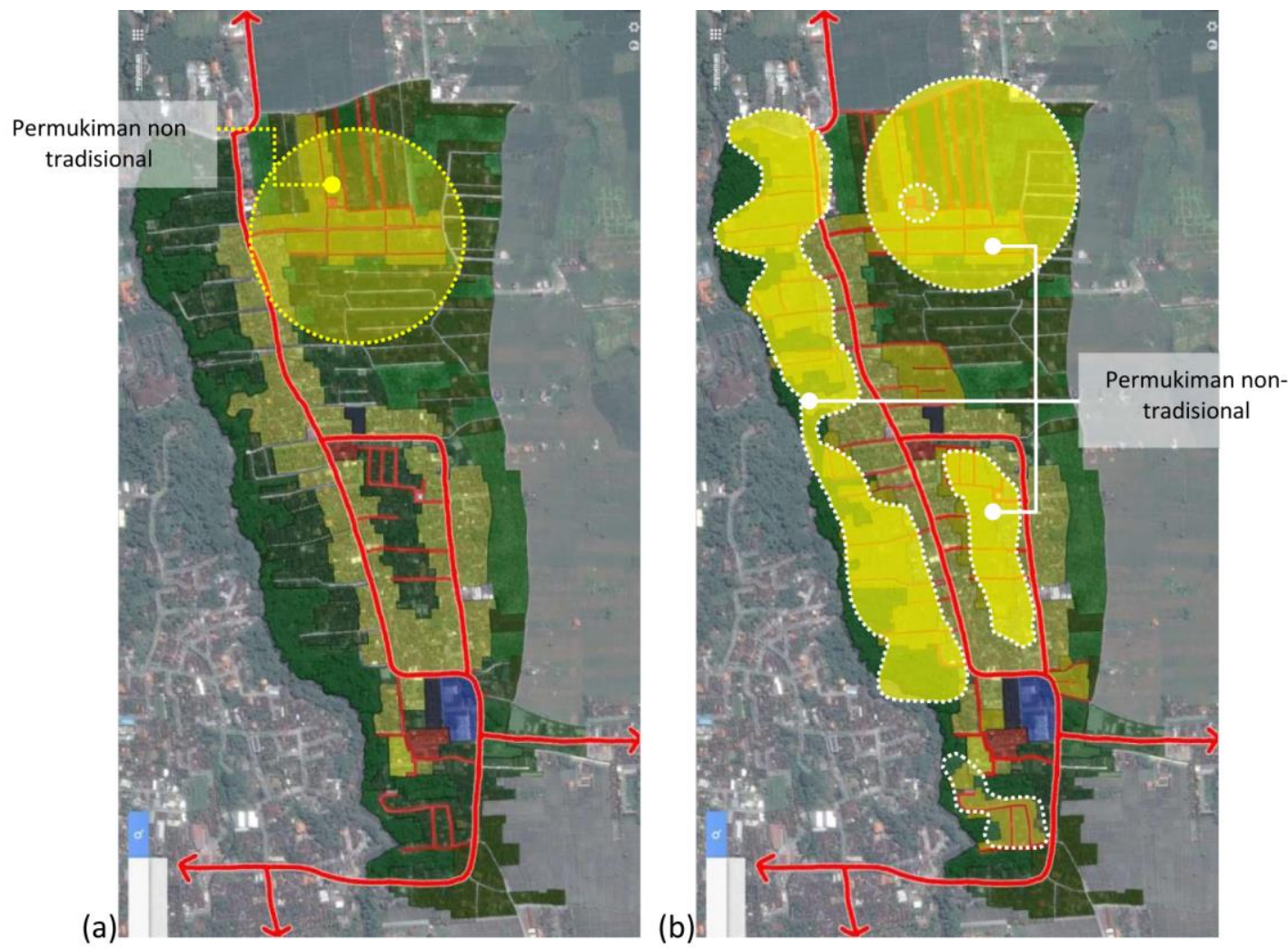

Figure 4. The Pattern of development of non-traditional settlements in Traditional Village of Peninjoan. Source: Field observations, building surveys and interviews, 2016

Physically, especially when viewed from the main road, changes in settlement patterns are not very visible. This is due to the position of the new houses which are behind the traditional houses of the native inhabitants of the Traditional of Peninjoan. What happened in the next development, starting from the 2010s until today, is that non-traditional settlements are starting to be expanded in all directions. Traditional considerations are, seemingly, no longer an important matter. New houses are built on lands that were once fertile land for agriculture and on lands that are geographically at risk of receiving natural disaster hazards, especially landslides.

Today's spatial and physical development trends, especially over the past decade, have shown that cosmological concepts have no longer been taken into considerations. Then, what factors are taken into consideration? It seems that economic values play a greater role in land selection. Agricultural lands are no longer considered capable of meeting the increasing needs of life. Additionally, being a farmer is no longer the preferable profession for the inhabitants of Traditional Village of Peninjoan. Agriculture, especially among the younger generation, has lost its prestige. From surveys and interviews conducted in 2016, it was revealed that the youngest farmer who still worked in the rice fields was those aged 49 years old, while the average age of the farmer was 59 years. As the average age of farmers increases, the understanding of natural conditions and local geography, as a basis for cosmology, also fades.

Youth are more interested in other fields which produce more economic benefits. These fields include tourism and employment in the world of government. Both of these fields are relatively new compared to thousands of years of agriculture. Despite being still relatively new, these two fields are more preferrable since they provide competitive income and a superior image. Farmers are associated with professions that are outdated, providing low income, and making 'dirty' for the is a requirement of dealing with land. Poor images of agriculture make it no longer attractive. As a result, fertile lands lost their potential cultivators, as well as their economic potential. This decline in economic potential is exploited by investors and developers to convert agricultural land into settlements. In the 2000s, most land, both fertile and infertile, was already filled with buildings (see figure 5). 


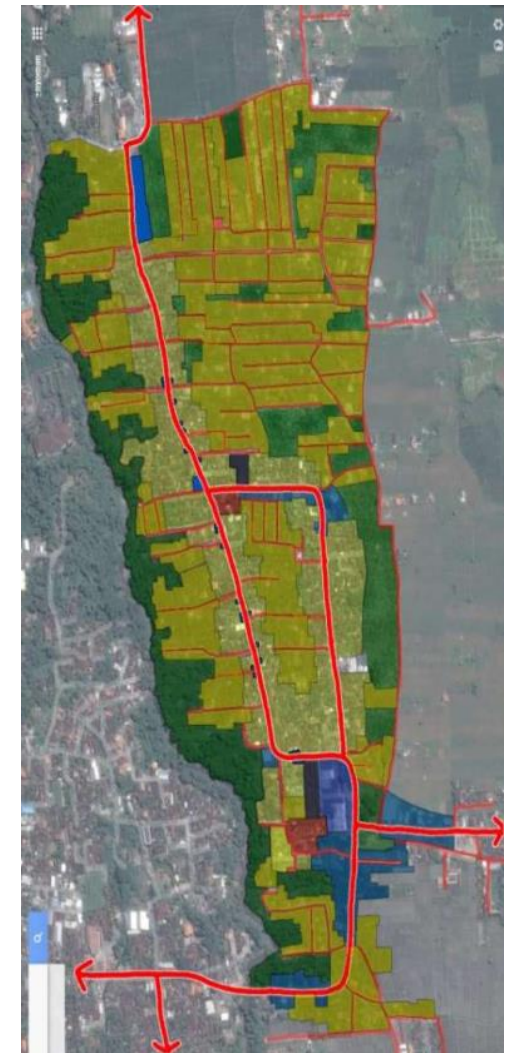

Figure 5. The yellow color shows that traditional and non-traditional housing is mixed. Source: Field observations, building surveys and interviews, 2016

The rapid increase in population also brings other benefits for indigenous people, or traditional residents. The large number of new settlements, which are inhabited by those who work in the sectors of government and tourism, has opened up opportunities for economic activities. The Traditional Village of Peninjoan takes advantage of this opportunity by renovating the village market. The market which was initially relatively small, is now increasingly expanding and selling agricultural products and its own processed products, prepared food, and daily necessities. Many residents open businesses in the market, abandoning their agricultural lands which have turned into settlements. New jobs, which offer economic benefits, also contribute to land conversion because people, economically, benefit more from this condition.

\subsection{Community Perception of Changes in Peninjoan Village}

The economic advantage gained by the community does not mean that it really results in their satisfaction. This was revealed from their perception of the current situation of the Peninjoan Traditional Village. To complete the spatial and building survey, a survey of people's perceptions of the environment in which they live is also conducted. Thirty people were interviewed in depth in relation to the physical transformation of the Peninjoan Traditional Village. From the results of the survey, it is uncovered that the public has several complaints. These complaints are related to quality of life, especially those related to social values.

Although some are satisfied with their economic life, people have complaints about development that focus on the economic approach because it is deemed having undermined their local identity as farmers. This is reflected in their statement confessing that the modern development has eliminated the traces of the past made by their ancestors. The community, on the other hand, also enjoys the new life giving them subsistence. The market situation is perceived bringing about a positive impact as it makes the village atmosphere livelier. 


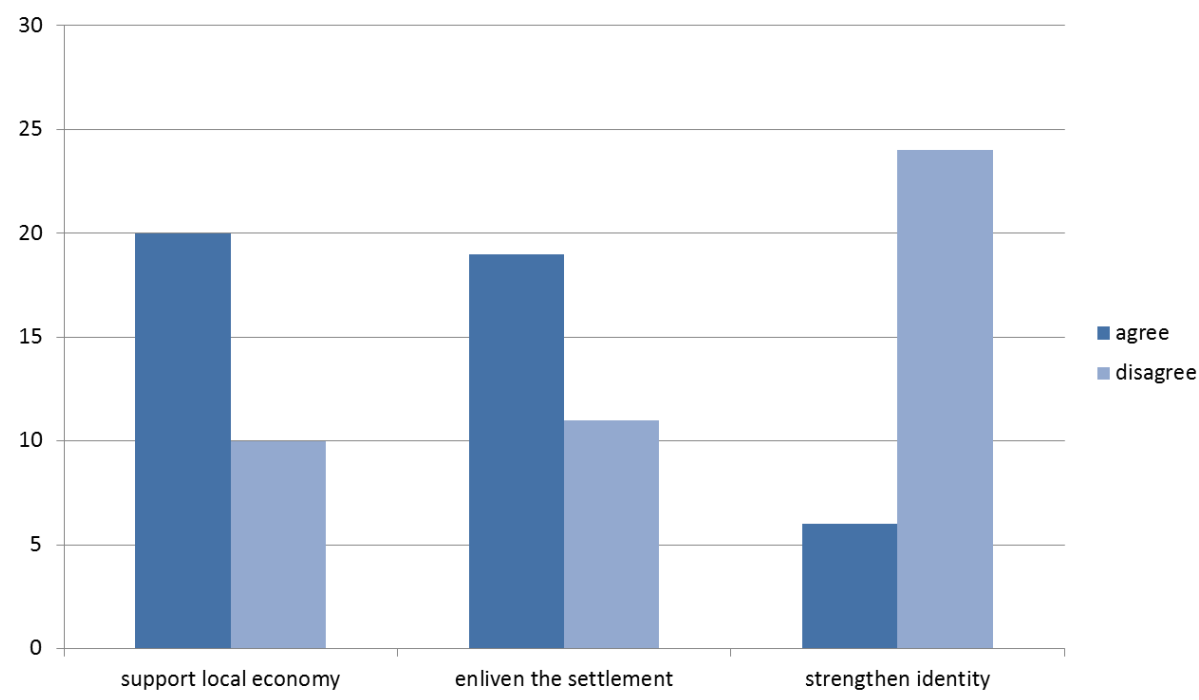

Figure 6. Figure of people's perception of development that prioritizes economic factors.

Source: 2016 in-depth interview

Physical development, which makes the economy come alive and villages have sufficient funds to carry out developments, encouraged the community to appreciate it. Funds obtained from the improvement made on market performance are used to repair temples and finance rituals so as not to burden the society. The development of new settlements also made the government pay more attention to road conditions. The village road, which was originally in the form of land, has now been paved. This enlivens the economy because the goods and services can be distributed more quickly.

However, the development has sacrificed two things that can improve the quality of life, such as open space and green space in the form of river borders. Road construction has eroded the function of the village centre, which initially served as a centre of social activity, but has now become a place for motorised vehicles to pass. Open spaces are now very limited to temple and market pages. The construction of new settlements also does not provide adequate quality in terms of providing open space. Social spaces can hardly be found in new settlements built by investors, leading to dissatisfaction of residents. The same case happened to the green spaces on the edge of a cliff that used to be in the form of fields with thick trees resembling a forest. Now the green spaces have turned into settlements. The table below shows the different views of the community towards the development in the non-traditional era.

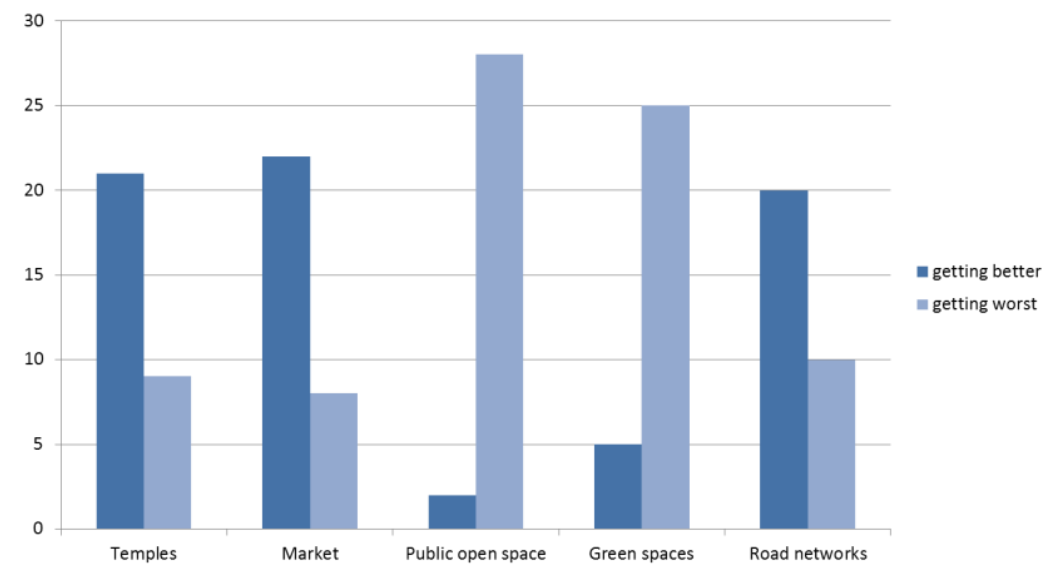

Figure 7. Population opinions on the effects of massive physical development in 2000s. Source: 2016 in-depth interview.

\section{CONCLUSION}

From the results of study on the physical and perceptual transformation in relation to disaster vulnerability in Traditional Village of Peninjoan, several points can be taken into conclusion.

As a traditional village, in the early days of its establishment, the village founders were very concerned about natural factors that could provide them with safety and prosperity. This is reflected 
in the spatial planning. Spaces that are estimated to be unsafe from the threat of disaster are designated as conservation areas by leaving them green. Therefore, spaces on the edge of a cliff are not permitted to be used as building locations. The same thing, not permitted to be built, is also embedded in fertile lands that provide economic benefits. As a community that relies on wetland agriculture, Peninjoan Village residents only build on infertile land that is difficult to get water. Fertile land with abundant water is used to develop agriculture.

The development of Peninjoan Traditional Village cannot be separated from the growth of the surrounding area, especially after Bali joined the Republic of Indonesia. The village, which was originally independent, now has to adjust to political policies that indirectly have an impact on its territory. The designation of Denpasar as the provincial capital has made it economically attractive. Similarly, the establishment of Sanur as the main tourist area. These two regions, which in traditional times had little impact on Peninjoan, have influenced the Peninjoan in the present. The economic growth of the city and Sanur invite many migrants who need land at affordable prices. This has an impact on the shifting of land functions, both in the form of green space conservation and productive agricultural areas.

The change in the function of agricultural land was economically well replaced by the enlargement of the village market. Farmers who lose their fields and their families can find work in the trade and services sectors. Some families also work in the tourism and government areas in the city centre. This has led to a decrease interest in working at the agricultural sector. Declining interest in working at the agriculture sector, increasing demographic pressures and a strong pull factor of the city centre have led to the transformation of traditional villages. In Peninjoan traditional village, the transformation occurred in land use. Land that was once a conservation area has been turned into developed land. The same thing happened to paddy fields which lost their economic value. This transformation shows the different paradigm of development. If in the tradition period, natural factors become the reference, in the present economic factors are the benchmark. This can have an impact on settlement vulnerability to disasters.

Disasters can come at any time. Living by considering the vulnerability of an area to disasters can minimise the number of victims who fall due to disasters. In a time when economic factors play a vital role, it is better to look back at the traditional principles in managing the settlements. There is a lot of hidden knowledge that can be reutilised and reactualised to prevent disasters. This does not mean that we have to go back to the past but rather to be able to draw lessons from knowledge that has been passed down from previous generations. By evaluating and actualising the tradition, it will stay alive and still have a place in this instant era.

\section{References}

Boeing, G. (2018). Measuring the complexity of urban form and design. Urban Design International, 23, 281-292.

Bourdier, J., \& Alsayyad, N. (1989). Dwellings, settlements and tradition: Cross-cultural perspectives. Lanham: University of Minnesota.

Carmona, M. (2019). Place value: place quality and its impact on health, social, economic and environemntal outcomes. Journal of Urban Design, 24(1), 1-48.

Dias, N., Keriminiyage, K., Amaratunga, D., \& Curwell, S. (2018). Crtitical success factors of a bottom up urban design process to deliver sustainable urban design. International journal of Strategic Property Management, 22(4), 265-277.

Hudalah, D., \& Woltjer, J. (2007). Spatial planning system in Indonesia. International Planning Studies, 12(3), 291-303.

King, A. D. (1991). Culture, globalisation and the world system: contemporary conditions for the representations. London: Palgrave MacMillan.

Kropf, K. (2009). Aspect of urban form. Urban Morphology, 13(2), 105-120.

Muhammad, N. M., Saruwono, M., Said, S. Y., \& Hariri, W. A. (2013). A sense of place within the landscape in cultural settings. Asia Pacific International Conference on EnvironmentalBehaviour Studies (hal. 506-512). London: Procedia-Social and Behavioral Science.

Oliver, P. (2007). Dwellings: the vernacular house worldwide. London: Phaidon Press.

Participation, I. A. (2019, December 2). Spectrum of Public Participation. Dipetik 2019, dari International Association for Public Participation: https://cdn.ymaws.com/www.iap2.org/resource/resmgr/pillars/Spectrum_8.5x11_Print.pdf

Permana, A. Y. (2014). Transformasi Gubahan Ruang: Pondokan Mahasiswa di Kawasan Balubur Tamansari Kota Bandung (Universitas Diponegoro). Retrieved from http://eprints.undip.ac.id/62084/ 
Sinamides, J. F. (2017). Transformation of vernacular architecture of the mountainous settlements of pomaks in Xanthi, Greece. Journal of the International Society for the Study of Vernacular Settlements, 5(1), 1-16.

Tjahjono, G., \& Miksic, J. N. (2003). Architecture: The Indonesian Heritage Series. Singapore: Archipelago Press.

Waterson, R. (1997). The Living House: An Anthropology of Architecture in South-east Asia (Paperback ed.). Singapore: Oxford University Press.

Watson, G. B., \& Bentley, I. (2007). Identity by Design. London: Architectural Press.

Zhang, M., Wu, W., \& Zhong, W. (2018). Agency and social construction of space under top-down planning: Resettled rural residents in China. Urban Studies, 55(7), 1541-1560. 